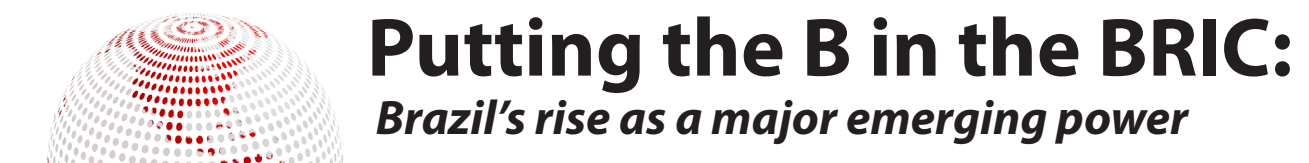

Gabriel Rodrigues,

Cornell University, 2012, Government Major

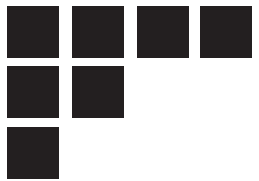

The world is rapidly changing and the new international order includes developing nations as powerful actors. Among them, Brazil stands out as one of the most influential and promising players. This article examines Brazil's case as an emerging major power in the international system. Despite several challenges it has yet to overcome, Brazil presents itself as a stable nation capable of being an economically and politically influential. This paper analyzes how Brazil is much more than just soccer, the Amazon, and Carnaval; in reality, it is becoming a powerful actor in the international system that does has a lot to offer.

Brazilians always had the hope that some day their country would launch off into an age of economic growth and stability. The promise of living in the "nation of future" has been present in Brazil even in the early $20^{\text {th }}$ century, when thousands of people immigrated dreaming of a better life. Unfortunately, the situation did not play out as nicely as they had hoped. Whether it was due to the fragility of the domestic political regime or its economic failures, Brazil was never able to reach this dream. In fact, Brazil has a long history of ups and downs. All of its booms were short-lived - the milagre economico (economic miracle) of the 1970s, for instance, was quickly followed by a ride with hyperinflation and increasing public debt in the 1980s. Brazil re-established a democratic regime in 1985 with the hopes of beginning a new era of progress and stability. Twenty-five years later this goal is, for the first time, tangible.

Brazil now enters the $21^{\text {st }}$ century as one of the main emerging powers in the world. Brazil's influence abroad increased tremendously in the last decade. Whether it is in speeches over global issues at the United Nations or at meetings of the world's biggest firms, it seems clear that Brazil is no longer overlooked. This only happened after Brazil finally reached political and economic stability, positioned itself as an international leader, and demonstrated the virtues of several of its unique characteristics. After years of struggle and little self-esteem, Brazil now emerges out of the biggest crisis in 80 years as the prominent leader for Latin America.

\section{Lingering Challenges}

Before Brazil can claim its status as a major power, it must first respond to the calls to improve the standard of living for its citizens. First of all, most of the population still experiences extremely low levels of socio-economic development. Brazil's universal healthcare system does have certain strengths (such as its renowned free AIDS treatment program), yet in general it is highly underequipped given the population's increasing needs. Similarly, the public education system is flawed; primary and secondary schools are falling to pieces, professors are unprepared, and many Brazilians barely know how to read and write. Except for a handful of top-tier institutions, most universities are either public and badly funded or private and greedy. On top of all of that, the government still has to deal with increasing levels of urban violence and the ineffectiveness of its law-enforcement institutions. Despite its economic progress, millions of Brazilians still live with these issues and are unable to fully reap the benefits of the country's growth.

Brazil also has problems with certain governmental actions in political and 
economic affairs. One of the biggest setbacks is a lack of fiscal austerity. Recent data shows that taxes amount to about $36 \%$ of the GDP, a level similar to those of Scandinavian states, where people can better afford to pay that much. This money fuels the government's excessive spending, which actually rose from $7 \%$ to $32.5 \%$ of the GDP in the last 14 years. ${ }^{1}$ The state, however, only directs a fraction of that to efforts to ameliorate the problems of poor Brazilians. Such inefficiency by the government generates inflation and forces cuts in areas such as education and healthcare. Not only do these levies inhibit investment and innovation, their complexity also adds the bureaucratic inefficiency known as the Custo Brasil ("Brazil Cost"). ${ }^{2}$ Many taxes overlap and the rifts between federal, state and municipal governments over how much each of them should get leaves space for corruption and mismanagement. Moreover, the lack of adequate fiscal reform can threaten long-term economic stability, curb social welfare, and crowd-out investment. In spite of so many difficulties, Brazil now has many reasons to consider itself as a major power on the rise.

\section{Economic and Political Stability}

After years of many ups and downs, Brazil's accomplishments in the last couple decades grant it a new level of political and economic stability. From 1985 to 1994, Brazil underwent a series of failed economic plans that seriously jeopardized its stability. In the first five years after re-democratization, the government implemented artificial methods - such as forcefully "freezing" prices and removing zeros from the currency - to control the rampant stagflation, all of which failed. The initial political turmoil instigated fears of what would happen, but Brazilians once again had the hope that things would improve for them. Unfortunately, the country spent nearly a decade fighting hyperinflation, rising unemployment rates, increasing budget deficits, and suffocating pressure from its foreign lenders, namely the International
Monetary Fund (IMF).

In 1994, however, President Fernando Henrique Cardoso came to light with a different strategy. Cardoso, a knowledgeable sociologist and former finance minister, had helped develop a viable solution to Brazil's

\section{"After years of struggle and little self-esteem, Brazil now emerges out of the biggest crisis in $\mathbf{8 0}$ years as the prominent leader for Latin America."}

economic problems. Under Cardoso's regime, the government developed the Plano Real, a new economic package that had as its core the mission of curtailing inflation, stabilizing the economy, and creating a new, solid currency. Cardoso's presidential campaign was largely successful because, as poor citizens, Brazilians feared the "monster" of inflation more than anything else. From 1993 to 1997, his actions curtailed the official inflation rate from $2,477.15 \%$ a year to just $5.22 \%$. $^{3}$ The new real established parity with the American dollar, which in turn triggered new investments. Cardoso also privatized some sluggish public companies that operated as quasi-monopolies in vital sectors (such as mining, energy and telecommunications). In spite of certain successes, Brazil was still very frail and it quickly succumbed to a series of international economic tribulations. The crises of Russia and the Asian "Tigers" posed serious threats to the domestic economy and demanded strenuous efforts from both the public and private sectors. By 2002 the Brazilian economy still lingered and all branches of government suffered from corruption. Cardoso was still able to lawfully add a second term to his presidency, but after a challenging but meaningful administration, he handed over the power to the leftist union leader and his political archrival, Luis Inácio "Lula" da Silva.

Lula, as he is commonly known in Brazil, co-founded the Partido dos Trabalhadores (PT, or Worker's Party) and had 
already run for presidency three times. His victory in 2002 generated mixed feelings at the time. His supporters saw him as a genuine Brazilian that grew up in a poor family, did not attend high school, and moved up in life starting as a low-class, blue-collar worker. His dissenters, on the other hand, viewed him as an extreme socialist that was willing to reverse Cardoso's policy in favor of an "anti-Western" Brazil. This abrupt change from a right-wing to a left-wing regime generated fear, especially abroad. Many economic and political analysts instantly questioned whether Brazil really deserved to be in the select group of the BRIC (Brazil, Russia, India and China). Brazil was overwhelmingly discredited and it looked like everything would go wrong again, but Lula, in the end, proved to be a moderate and skillful leader.

On the economic front, Lula continued Cardoso's successful policies, and he kept all of the promises the past administration had made. Despite objections from within his own party, he maintained the regime of fluctuating, market-ruled exchange rate, and prioritized primary surplus - committing an established percentage of the GDP to pay off debt. With this, Brazilian public debt fell from nearly $60 \%$ of the GDP in 2002 to around $40 \%$ in the first months of 2009. ${ }^{4}$ Another measure he preserved was inflation-targeting, which preserved the government's commitment to containing any abnormal price level spikes. Lula also nominated former BankBoston CEO Henrique Meirelles to the presidency of the Brazilian central bank; Meirelles gave the leftist administration more credibility with international investors, and his autonomy to stipulate interest rates and monitor exchange rate policy ${ }^{5}$ proved that the extremist political rhetoric of Lula's leftist peers was not allpowerful. Furthermore, Lula reaped the benefits of this decade's economic boom to surf the "commodity wave." With the increasing demand of raw materials from powerhouses like China and India, Brazil took advantage of rising exports and global commodity prices to exponentially increase its net trade surplus. Consequently, the government was able to accumulate, as of October 16, US\$ 232 billion in international reserves ${ }^{6}$ and repay longtime lenders.

On the political front, Lula's success has been more limited. Despite its recent improvements, Brazil still suffers from much corruption. In the seven years he has been in power, Lula has seen at least two of his main ministers step down due to corruption charges, and Congress has become a center of national discontent. By the time of his re- election in 2006, Lula had already seen many key political figures of his party being prosecuted. Nonetheless, this does not seem to hinder the president's political strength. Boasting an approval rate of over $76 \%$ even after the crisis, Lula is the most popular leader in Brazil's recent memory. His economic success and his social policies, especially with the extremely poor citizens, are the reasons. His Bolsa Familia, a welfare program that transfers money to poor families, unified and expanded the policies previously implemented by Cardoso. It offers the extremely poor citizens a means to earn money as long as their children attend school and take all vaccines they need. In the last six years, the Bolsa Familia, coupled with the country's economic growth, made 31 million Brazilians move up in social class. In fact, from 2003 to 2008, the percentage of Brazilians that earn less than US\$ 450 a month decreased $43 \% .{ }^{8}$ Brazil's democratic regime and Lula's choice not to change the constitution and run for a third mandate offer a completely different picture than what one usually encounters in Latin American politics. Brazil is now committed to stability and socioeconomic development, not to populist ideologies or coup d'états.

\section{International Leadership}

Due to this recently achieved economic and political stability, Brazil is now Latin America's main leader and a prominent global player. In the domain of international relations Brazil 
has a rising influence.

Brazil's international leadership is first evidenced in its ties with its Latin American counterparts. Its relationships with certain countries, like Chile and Peru, have always been amicable, but other nations are more problematic. Hugo Chavez, for example, uses his "Bolivarian revolution" as a means to criticize the Western powers and gain support from Venezuela's underprivileged classes. In spite of his inflammatory comments, Brazil doesn't adhere to Chavez's rhetoric and tries to establish a cooperative relationship. An example is the attempt for a multi-billion dollar joint venture between Brazilian oil mogul Petrobras and its Venezuelan counterpart PDVSA to build a refinery. ${ }^{9}$ Brazil also tries to appease the complaints of underdeveloped nations like Bolivia and Paraguay. In many instances, Brazil gave in to several of their demands, alleging that it had no interest in taking advantage of its poorer neighbors and that the welfare of South America as a whole was in Brazil's best interest. This is the reason why President Lula has worked hard recently to promote regional cooperation and pragmatism through the Union of South American Nations (UNASUL). ${ }^{10}$ Although Brazil

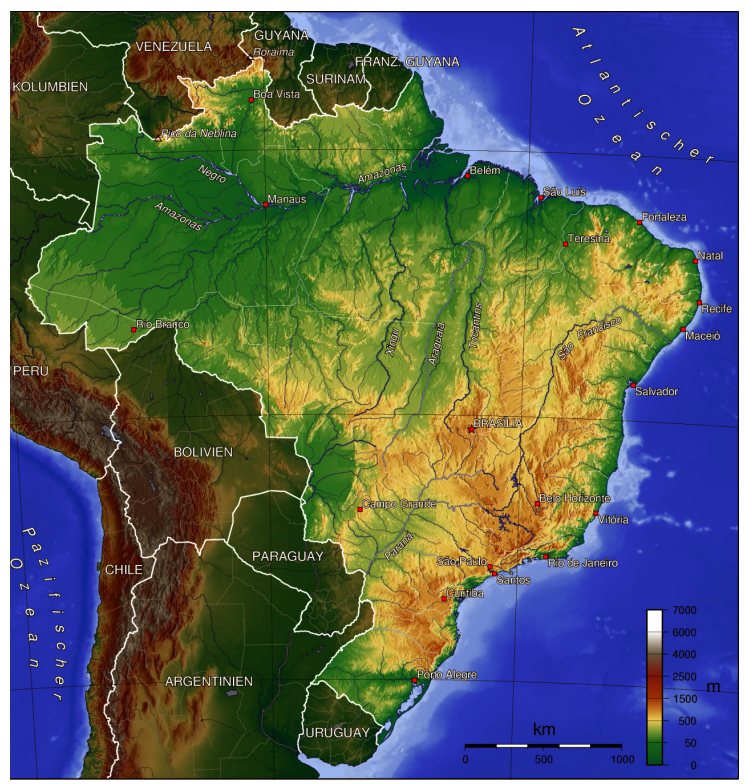

The "pré-sall" oil reserve, discovered off Brazil's coast, holds 5 to 8 billion barrels of oil should be careful not to appear too passive, such attitude demonstrates the country's willingness to cooperate.

In an attempt to show its concern with human rights and security, Brazil also decided to lead the current UN peacekeeping operation in Haiti. After the local government collapsed in 2004, Brazil promised to help the poorest nations in the Americas overcome widespread violence. The mission has had its low points, but one of its greatest achievements yet was the friendly soccer match between the Brazilian squad and Haiti. Soccer stars like Ronaldo, Ronaldinho and Kaká showed how Brazil's "friendliness" was more profitable than any sort of military action. Regardless of the result of the match, millions of Haitians forgot all of their problems for an entire day to cheer and parade with their idols through the streets of Port-au-Prince.

In a broader context, Brazil views alliances between developing nations, or socalled South-South cooperation, as a vital part of its international agenda. In the past, developing nations could hardly interact with one another unless a developed nation worked as a liaison. What Brazil currently envisions is a new global order, where the global South can interact independently of the North. This process involves other major rising powers as well, but President Lula has made SouthSouth cooperation one of the biggest issues of his foreign policy. As a consequence, Brazil is turning into a meaningful player in different regions of Africa and Asia. Leading Brazilian companies have installed offices all over, from Mozambique to China. Likewise, the Brazilian government has made some attempts to show its benevolence to its Southern peers. The Brazilian Agricultural Research Corporation (Embrapa), a leading institute in agricultural research and technology, recently built their first African office in Ghana. The technology Embrapa studies can help local farmers produce better crops as well as develop biofuels. ${ }^{11}$ All of this effort has proven to be very successful, especially because 
most underdeveloped nations tend to trust developing powers like Brazil, China and India more than Western powers.

Considering its recurrent presence in global debates, Brazil now asserts its role as a prominent player in international politics. First of all, Brasilia's influence in economic bodies like the World Trade Organization (WTO) and the IMF is growing exponentially. As an exporter nation and advocate of free and fair trade, Brazil has successfully used the WTO to solve its disputes (such as its complaints against American subsidies on cotton.) Moreover, in the current debates about the financial crisis, Brazil became, for the first time in its history, a lender nation to the IMF. This is unprecedented for a country that, only a decade ago, depended on IMF loans and suggestions to run its economy. In the United Nations, Brazil holds a stronger presence and aspires to hold a permanent seat on the UN Security Council as a Latin American representative. The creation of G20 also indicates a global recognition of Brazilian influence in politics and economics. In the last summits in London and Pittsburgh, President Lula and the central bank's Meirelles urged nations worldwide to cooperate, signaling that the new global order resides beyond the archaic G8.

\section{The Future is Not Just \\ Soccer and Carnaval}

Brazil's recent stability and accomplishments in foreign policy do grant it the title of Latin America's most powerful nation. Nonetheless, there are six other factors that can now (and in the near future) make its status as a rising major power even stronger.

First, Brazil has, as one of its greatest assets, its natural resources. Brazilian soil is extremely fertile, the land is relatively flat, and fresh water is abundant. It comes to no surprise then that Brazil is currently the world's largest produce of beef, poultry, coffee, sugar and ethanol. The Amazon forest, although mismanaged, is still the world's largest ecosystem; opportunities for sustainable development and carbon trade are privileges Brazil can profit on at anytime. It is also worthwhile to mention that Brazil is immune to natural disasters like earthquakes, volcanoes and hurricanes. All of these factors allow the country to become a great player in the commodity market. Brazilian Vale S/A, for instance, now uses its status as the world's second largest mining company to stipulate prices that clients (like China) have to pay for iron ores. ${ }^{12}$ In addition, Brazil recently discovered a humongous oil reserve right off of its coast. Labeled as pré-sal (pre-salt), this reserve sits under a layer of salt that is several kilometers thick, and it holds about 5 to 8 billion barrels of oil. ${ }^{13}$ With the prospects of oil revenue, Brazil already created its own sovereign fund, and private investments in infrastructure and technology are booming. As developing countries grow and consume more, Brazil will profit from being one of the world's main suppliers of raw materials.

Secondly, Brazil's cultural and historical background makes it a cohesive and relatively peaceful nation. Unfortunately, violence is still very present in day-today life. Cities like Rio de Janeiro do have drug warlords dominating the slums, and authorities are still very unprepared to deal with the situation. Nevertheless, this violence arises due to socio-economic factors. A thief will rob or kill because he is poor, uneducated, and unemployed; if they have no hope of moving up in life, crime would most likely be their last resort. The situation may at times be dire, but economic development and proper education could reduce these crime rates. This is not the case with some other nations. The Russians cannot apply the same rationale to resolve their issue with the Chechens, nor can China with the Tibetans. Brazil has no Georgia, no Taiwan and no Kashmir. It has no nuclear weapons, and no historical tension with any other nation abroad. In fact, the closest Brazil gets to an international conflict is when it plays soccer with its longtime archrival Argentina. 
Third, Brazil's current democratic regime is considered legitimate. Historically, Latin American politics have a tendency to be extremely volatile. It always seems that with every new politician, fake promises, corruption and exploitation reappear. The last two administrations, however, have proven that this condition is not universal. The two past Brazilian presidents came from opposing parties and had disparate ideologies, but they still knew the importance of legitimizing the newly established democracy. Brazil did not succumb to populism like Venezuela or Bolivia, it does not face the possibility of a one-party system like Mexico, and it did not cave in to self-interested, oblivious leaders like Argentina. Despite the remaining political tension within the legislative and other spheres of power, the Brazilian democracy as a whole is more consolidated.

Fourth, Brazil emerges out of this economic meltdown more resilient than before. Unlike what happened in previous years, this crisis passed by relatively swiftly in Brazil. The drops in the financial and real economies happened, but they did not last long. São Paulo's Bovespa/BM\&F is now the world's fifth largest stock exchange and its main index, the lbovespa, has already returned to pre-crisis levels. In fact, the largest IPO of 2009 to this date came from a multinational headquartered at Brazil. ${ }^{14}$ Brazilian banks swam against the current, as they kept posting profits even at the peak of the downturn. The local financial system is relatively immune to what happened abroad because Brazilian banks are well-hedged, not too exposed to international markets, and then do not take excessive risks. In fact, banks benefit from the new healthy increase in domestic consumption and credit. As to the real economy, the effects of the crisis also seem to fade away. Industry and agriculture, which depended more on exports, took a heavy hit, and this lead to many lay-offs. Expectations, however, proved to be worse than the reality. Businesses are re-hiring their former employees and, in some cases, even increasing their workforce. Consequently, Brazil posted in September of 2009 an unemployment rate of $7.7 \%$, lower than that of the US. ${ }^{15}$

Fifth, Brazil already demonstrates certain virtues typical of developed powers. More than half of its electricity comes from carbon-free hydroelectric plants, and around three-quarters of the news cars sold are biofuel. Ethanol is one of Brazil's greatest economic and environmental assets. Unlike the corn ethanol produced in the US, Brazilian ethanol comes from sugar cane. The advantage of this variety is that it is cheaper, more efficient and it uses a raw material not vital for humans (and thus, not affecting food supplies). ${ }^{16} \mathrm{~A}$ popular misconception is that Brazilian farmers deforest the Amazon to create space for more sugar cane fields; in reality, most plantations are located thousand of miles away in the São Paulo state and new farms emerge in unpopulated open plains southeast of the Amazon.

Another strong trait Brazil has is the power of its private sector. Not only do Brazilian banks, oil, mining and construction companies rank highlycompared toitsforeign counterparts, but other industries also show rapid development domestically and abroad. Embraer (which was once owned by the state) is now the world's third largest airplane manufacturer, while the Belgian-Brazilian InBev recently purchased Budweiser, America's largest beer company. Brazilian capitalism now flourishes stronger than ever, ready to succeed in a competitive and globalized world.

Sixth, Brazil's image abroad grants it a degree of soft power. Brazilian culture, soccer and lifestyle generally interest and appeal to people. It attracts immigrants and tourists from abroad, and having a good reputation is key for a state to convene its power. Moreover, Brazil also profits on its own image abroad; the brand "Brazil" sells various commodities, like flip-flops and soccer jerseys. Not surprisingly, this soft power may have influenced the global community in awarding the 2014 FIFA World 
Cup to Brazil and the 2016 Summer Olympics to Rio de Janeiro. This appeal attached to Brazil's image is constantly reflected in its international interactions. Brazilians feel welcome anywhere they go, and most people associate their first thought of Brazil to something positive. That might also account for why few (if no) states view Brazil as an enemy. In fact, Brazil is a rare case of a nation who is rising without making other nations feel bothered or insecure. Brazil's charisma and relatively untainted reputation are definitely unique assets few other developing countries possess.

\section{Conclusion}

The current state of Brazilian economy and politics does consolidate it as an emerging major power. Despite all of the challenges it still has to overcome, everything seems to be working in Brazil's favor. Its recent stability on both the economic and political fronts make it stand above many other developing countries. Not only that, but Brazil's impact abroad and its domestic qualities make it stand out even more. In 2010 Brazil will once more hold elections and a new president will emerge. The top two candidates (one of whom has a $\mathrm{PhD}$ in Economics from Cornell) come from opposing parties, and possess different views on what the government should do. What they do share, though, is the vision of Brazil as a global leader. Regardless of the outcome of this election, it is very unlikely that Brazil will derail. A lot still has to change and Brazil should not get ahead of itself, but for now it can claim that its ascension to the pantheon of major powers is legitimate.

\section{Endnotes}

"Economic Survey of Brazil 2009: Reforming indirect taxes and labour levies." Organization for Economic Co-operation and Development. 14 July 2009. http://www.oecd.org/document/10/0,3343,en_2649_34111_43225546_1_1_1_1,00.html

Samuels, David. “Fiscal Straitjacket: The Politics of Macroeconomic Reform in Brazil, 1995-2002. Journal of Latin American Studies 35.3 (August 2003): pp. 545-569. JSTOR.

3 "Inflação: IPCA". Instituto de Pesquisa Economica Aplicada. 27 January 2009. http://www.ipeadata.gov.br/ipeaweb.dll/ipeadata?SessionID=13442 74515\&Tick $=1256866767008 \&$ VAR FUNCAO=Ser Pan\%28\%29\&Mod $=\mathrm{M}$

4 "Economic Survey of Brazil 2009: Reaping the benefits of macroeconomic consolidation." Organization for Economic Co-operation and Development. 14 July 2009. http://www.oecd.org/document/37/0,3343,en_2649_34111_43225253_1_1_1_1,00.html

"Brazil's Recovery | Juggling technocrats and party hats." The Economist. 15 October 2009. http://www.economist.com/world/americas/ displaystory.cfm?story_id=14644374

6 Brasileiro, Adriana, and Soliani, Andre. “Brazil to Impose Tax on Foreign Inflow, Mantega Says." Bloomberg. 19 October 2009. http://www.bloomberg. com/apps/news?pid=newsarchive\&sid=aDOrGaLDZOCo

Guerreiro, Gabriela. "Aprovação do governo Lula oscila quatro pontos para baixo, diz pesquisa." Folha de São Paulo. 8 September 2009. http:// www1.folha.uol.com.br/folha/brasil/ult96u620791.shtml

8 Leitao, Thais. "Ascencao social beneficiou 31 milhoes de brasileiros entre 2003 e 2008, revela pesquisa." Agencia Brasil. 21 September 2009. http:// www.agenciabrasil.gov.br/noticias/2009/09/21/materia.2009-09-21.7187639536/view

9 Watkins, Eric. "Petrobras, PDVSA agree to terms of Abreu e Lima refinery." Oil \& Gas Journal. 8 October 2009. http://www.ogj.com/index/articledisplay/1901440632/articles/oil-gas-journal/processing-2/refining/construction/2009/10/petrobras_-pdvsa_agree.html

10 "Brazil's foreign policy / Lula and his squabbling friends."The Economist. 13 August 2009. http://www.economist.com/world/americas/displaystory. cfm?story id $=14229460$ s

11 "Presidentes do Brasil e de Gana conhecem atuação da Embrapa na Africa. Embrapa. 24 April 2008. http://www.embrapa.br/imprensa/ noticias/2008/abril/4a-semana/presidentes-do-brasil-e-de-gana-conhecem-atuacao-da-embrapa-na-africa/?searchterm=gana

12 "Vale discounts iron ore for China clients." Reuters. 20 April 2009. http://uk.reuters.com/article/idUKN2039057120090420

13 "Petrobras starts producing in the Brazilian pre-salt pole." Petrobras. 1 May 2009. http://www.petrobras.com:80/ptcm/appmanager/ptcm/dptcm? $\mathrm{nfpb}=$ true\&_windowLabel=petr_com_noticias_noticias\&petr_com_noticias_noticias_actionOverride $=\% 2 \mathrm{Fbr} \% 2 \mathrm{Fcom} \% 2 \mathrm{Fpetrobras} \% 2 \mathrm{FportalPe}$ trobrasPontoCom\%2Fapresentacao\%2Fnoticias\%2FexibeNoticia\&petr_com_noticias_noticiasidConteudoPrincipal=noticias_detalhe_00063

14 Cowan, Lynn, and Jelmayer, Rogerio. "Year's Biggest IPOs Make Debuts." Wall Street Journal. 8 October 2009. http://online.wsj.com/article/ SB125490518369670353.html

15 “Pesquisa Mensal de Emprego - PME." Instituto Brasileiro de Geografia e Estatistica. September 2009. http://www.ibge.gov.br/home/estatistica/ indicadores/trabalhoerendimento/pme_nova/pme_200909tm_01.shtm

16 Hirsch, Tim. "Brazil's Carbon Challenge."World Watch. 22.4 (July/August 2009): pp. 30-35. SocINDEX.

Photo Courtesy of:

"Map of Brazil." Wikimedia. 31 Oct 2009. http://wikimediafoundation.org/wiki/File:Brazil_topo2.PNG 